\title{
Bringing globalisation to the countryside: special economic zones in India
}

\author{
Mohammad Amir Anwar ${ }^{1}$ and Pádraig Carmody ${ }^{2}$ \\ ${ }^{1}$ School of Tourism and Hospitality Management, University of Johannesburg \\ ${ }^{2}$ Department of Geography, Trinity College Dublin and Department of Geography, \\ Environmental Management \& Energy Studies, University of Johannesburg
}

Correspondence Address: STH Admin Building, University of Johannesburg Bunting Road Campus, Auckland Park, Johannesburg, 2006 South Africa

Email: anwarm@tcd.ie

Telephone: $+27-115591143$

Keywords: Special Economic Zones, Neoliberalism, Globalisation, Land acquisition, dispossession, India

This is a pre-publication version 


\section{Introduction}

The Special Economic Zones (SEZs) policy was launched in India in 2005 and has a different character and geography from that of neighbouring China (Anwar, 2014). SEZs were expected to attract investment, both foreign and domestic, help infrastructural development, increase export earnings and generate employment. These zones marked a clear break from earlier statist model of development in India and gave priority to the development of a knowledge based economy and industrialisation over agricultural development. Arguably, sluggish growth in agriculture and its allied activities since Independence prompted the introduction of neoliberal policies in India - bringing globalisation and industrialisation to the countryside being the primary objective of the policy. As one member of the now defunct Planning Commission, Government of India, once put it, 'fragmentation of land holdings has made farming unviable, so government should rather consolidate the land holdings and use it for industrialisation’ (Santosh Mehrotra, Senior Adviser Planning Commission, interview NDTV 2007). ${ }^{1}$

Despite the proclaimed laudable goals of SEZs, no policy in India aimed towards globalisation and liberalisation of the economy has attracted as much controversy as this policy. A popular narrative amongst rural populations and activists is that these zones expropriate land from peasants, transfer assets from poor to rich and thereby exacerbate inequality and poverty in the rural areas, instead of promoting the promised development. This has resulted in nationwide resistance movements against SEZs and associated land acquisition, yet these zones continue to be established around the country. ${ }^{2}$ How can this be explained? 
The main objective of this article is to understand why, despite widespread resistance, neoliberal policies are being still designed and implemented in India. We argue that this relates to two key points. One is that the gradual introduction of neoliberal policies since 1991 have generated enormous opportunities of wealth accumulation for the country's economic elites, who therefore continue to push for neoliberal reforms. Secondly, the development of SEZs encounters the previously untouched sectors of the economy, namely land and labour, thus bringing the economic reforms into the domain of mass politics (Corbridge et. al., 2013). Therefore, neoliberal policies such as SEZs interact with local political and historical forces in the countryside producing varied and less co-ordinated resistance movements, which are often easily countered by the state by dividing them along the lines of class interests. We argue that these two processes of wealth redistribution towards the country's elites and the diverse class interests of the resistance movements further enable the proliferation of neoliberalism and its practices in the countryside. Through a grounded analysis of a SEZ in Gurgaon district of Haryana state in North India, this paper explores the ways in which special economic zoning, as a neoliberal policy, has been implicated in the spatialised production of poverty and its impacts. We also show that the main actors in promoting neoliberalism in India (the state and the large-scale urban private sector) have found a seemingly unlikely ally in rural India in the form of the large land holding farmersrural elites, who are willing to let go of their land under certain conditions.

The data for this article was collected during fieldwork in India in 2009-10. Semi-structured qualitative interviews were conducted with the local villagers in the area where the SEZ is located in Gurgaon district (Figure 1). In all 60 interviews were conducted with locals who were affected by land acquisition for the SEZ, who were identified using the snow-ball technique. To avoid biases, in terms of selection of respondents and in order to have variety 
of locals of different backgrounds take part, contact with two key informants proved useful. Out of 60 respondents, five of them were landless. Also, government officials in Export Promotion Council for EOUs [Export Oriented Units] and SEZs (EPCES) provided further insights into the workings of SEZs policy in India. All the names of the local respondents have been changed to protect their identity.

\section{Making sense of the SEZs: ultimate form of neoliberalism}

The growth and development of SEZs in India has been attributed to either a 'global strategy of capital' (Banarjee-Guha, 2008) or 'largely the product of mature Indian capitalist class', thereby representing a 'privatisation rather than foreignisation of the space' (Levien, 2013a: 396-7). We argue that instead of a dichotomous understanding, the development of SEZs in India must be understood against certain historical and geographical background.

India was the first country in Asia to introduce SEZs in 1965, albeit with little response from investors. 3 However, interest in the development of SEZs received renewed prominence amongst policy makers in 1990s. This was concomitant with a wider desire amongst the Indian politico-economic elite to adopt neoliberalism as a policy programme. The Indian government's adoption of neoliberalism in the post-1990 era was carried out against the backdrop of the economic crisis of India's state-led development model that reached its height in 1991 which was a product of both internal and external factors (Ahmad, 2014). Neoliberalism as an economic philosophy is based on the ideas of a "free" market and "free" trade, with the ultimate aim of promoting renewed and expanded capital accumulation, and the restoration of class power (Harvey, 2005). Certain key economic practices form the core 
of neoliberalism such as reduction in state welfare spending, privatisation of various social assets such as water, electricity, health and sanitation, deregulation of private sector entities and greater capital mobility. These features have spread around the world since the 1970s in large part due to the Structural Adjustment Programmes (SAPs) initiated by the World Bank (WB) and the International Monetary Fund (IMF) and have also been responsible for gaining ground in the Indian political economy.4

Economic reforms in India based on neoliberal practices such as the reduction of import and export tariffs, tax incentives for the private sector, removal of licensing restrictions and relaxation of controls on the entry of foreign companies were put in place in 1991 and are being carried out continuously. The reforms in India have been rolled out regularly albeit in a way to avoid direct confrontation with the masses through stealth and backhand deals highlighting the skilled nature of India’s ruling elites (Jenkins, 2011; Corbridge et. al, 2013). However, the earlier reforms did not touch the politically sensitive sectors such as agriculture, land and labour (Jenkins, 2011). Jenkins had identified three generations of reform with the first two focusing on efforts to liberalise the macro-policy environment and to create institutions to regulate a market economy. The third generation of reforms included the creation of geographical spaces of 'exception' (Agamben, 2005) for experiments in market "freedom" inside the prevailing domestic political economic system, which culminated with the introduction of SEZs policy (Jenkins, 2011). The SEZs policy Jenkins (2011) argued also help facilitate the global presence for India's private sector firms and rapid development of infrastructure in the country. 
With the SEZs Act of 2005, the Indian government sought to extend the new economic policy environment more deeply into the countryside through the creation of 'islands' of neoliberal space. SEZs were designed as pockets of exception where better infrastructural facilities and favourable laws on labour and tax than the rest of the country would help attract private investment.

The Indian policy makers thought that these would have wider economic benefits such as exports in high value added sectors, increased employment and rapid economic growth. SEZs were meant to become centres of knowledge-based Information Technology (IT) sector-led economic growth. Since 1990, India’s economy is dominated by services mainly in the IT sector such as software development, Business Process Outsourcing, and other IT enabled services (ITES). According to the National Association of Software and Services Company (NASSCOM), IT-BPO (Business Processes Outsourcing) sector have increased its share from four percent in 1998 to 26 percent in 2011 of India's total exports (NASSCOM, 2012 cf. Anwar, 2014).

Unlike the previous zones designed for export oriented industrialisation which were all in the public sector, the new SEZs policy is focussed on attracting investments from the private sector. Bureaucratic rules and procedures for establishing SEZs were streamlined and simplified such as single window clearance, relaxed environmental regulations, free provision of infrastructure and cheap power and water supply, along with hosts of other tax incentives. All of these were put in place to make private sector investment easier. The SEZs policy in India, therefore, forms one of the main axes of the neoliberalism in the country. 
Neoliberal reforms in India have opened up a field of competition between state governments to attract private investment both domestic and international. With the introduction of the SEZs policy, the state governments are competing with one another to provide land for the private sector in order to attract investments for these zones. Since, land under the Indian constitution falls under the jurisdiction of the state governments, they facilitate the acquisition and ultimate transfer of land to the SEZ developers whom Levien (2011: 459) refers to as 'capitalist rentier', who convert and commodify rural land for industrial, residential and commercial purposes. On the other hand, the Central Government monitors and governs these zones through the Ministry of Commerce and Industry, with the help of seven zonal Development Commissioners (DCs) in charge of all SEZs in the states under their jurisdiction.5 This kind of land acquisition and transfer is indicative of the privatisation of land and is becoming as a source of conflict against SEZs policy as discussed in the next section.

\section{The political economy of resistance against SEZs: the Gurgaon case}

Although dispossession and displacement from farmland has been a central feature of capitalism's historical development, its significance has increased as capitalist social relations have penetrated various world regions. Indian history is chequered with massive land dispossession during the colonial and post-colonial eras. During the Nehruvian state-led development era, land was expropriated by the Indian government for industrial and infrastructural development projects to produce goods for the market through various statelevel industrial corporations (SIDCs). ${ }^{6}$ Therefore, land acquisition for SIDCs represented a distinct 'regime of dispossession' where land was put to use for industrial production 
(Levien, 2013a). Although these projects had significant legitimacy due to they being state driven and generated significant employment, they also entailed dispossession and resistance movements against them (Levien, 2013a; Mathur, 2008). However, the vision of state-led development made the resistance movements less likely to gain wider support albeit with some notable exceptions such as Narmada Bachao Andolan (Baviskar, 1998). Nonetheless, recent estimates of development induced displacement in India between 1947 and 2004 puts the figure anywhere between 40 to 60 million people (Fernandes, 2008). However, land dispossession and the peasant resistance gained new attention when the policy of SEZs materialised in 2005. SEZs became the subject of 'land wars' in India (Levien, 2013b) after the massacre of 14 villagers/protestors in Nandigram in West Bengal on March 14, 2007 (People’s Tribunal on Nandigram, May 2007).

SEZs represent a neoliberal 'regime of dispossession' of 'land for the market' where land is expropriated by the state for private firms (Levien, 2013a). Under the SEZs policy land is now increasingly acquired by the state directly for its market value. Understandably, real estate firms have become the largest developers of SEZs in India accounting for roughly $60 \%$ of the all SEZs in India. Since $50 \%$ of the total area of any SEZ can be used for nonprocessing purposes, real-estate firms can use this area for development of housing, commercial and recreational spaces. Therefore, SEZs offered opportunities for real-estate firms to get access to huge amounts of land cheaply for speculative purposes in the hinterlands of centres of globalisation in India, like the cities of Gurgaon, Bangalore, Chennai and Noida, for example. 7 
Despite the Indian government rhetoric that the priority would be given for the waste and barren land and only if necessary then the farmland (both single crop a year and multiple crop a year agricultural land) would be acquired for the SEZs, this has happened unquestionably in the states of West Bengal, Haryana, Orissa and Uttar Pradesh (Government of India, 2009). Since these zones and their associated land acquisition interact and disrupt local agrarian structures, the sites for SEZs have become a source of resistance movements against these new models of globalisation in India.

The SEZ in question here was developed by Reliance Industries Ltd (RIL), one of India's the largest private-sector conglomerate, near the town of Gurgaon in the Haryana state. ${ }^{8}$ It was first announced on an area of around 12,000 hectares of land (a hectare of land is equivalent of 2.5 acres) (The Times of India June 20, 2006). However, the acquisition for the entire SEZ could not be completed because this project came under heavy resistance organised by the local villagers in the area. The state government transferred 133 hectares of land which was under the Haryana State Industrial Development Corporation (HSIDC). While the rest of it was either acquired from the locals with the help of the state government (The Telegraph, August 3, 2009). This SEZ was later 'notified' on November 14, 2007 over 440 hectares of land (Document obtained from the Ministry of Commerce and Industry, Government of India on June 19, 2009). ${ }^{9}$

Farm relations in Haryana have been dominated by the richer peasantry who own large land holdings and often belong to upper castes (Brass, 1999; Jodhka, 2012). However, the agrarian relations (land and labour) have changed in Haryana in the last thirty years. Since the economic reforms of 1990s, the large land owning households' newly acquired power comes 
not only from the huge amount of land owned by them but also from the urban centres (New Delhi, Gurgaon and Faridabad to name a few) through professional education and political connections (Jodhka, 2012). There is also evidence that cultivation practised by a large proportion of rich farmers is on the basis of contract farming, mainly carried out by migrant landless labourers often from lower castes (Brass, 1999; Jodhka, 2012). The interests of these classes often clash; most notably around their perceptions of land as the source of wealth and income versus livelihoods. The introduction of SEZs in the rural lands of Haryana comes as a direct challenge to the claims to land by these classes, resulting in further inter-class conflict between members of richer peasantry and the marginal and landless farmers.

This SEZ ran into trouble immediately after it was announced in June, 2006. Local villagers in the area formed the Kisan Jagrukta Samiti (KJS) (Farmers Awareness Committee) to organise resistance against the planned acquisition of land for the Reliance (Shrivastava, 2007). Meetings were organised by the affected villagers with protests on the roads and near the site of the SEZ being common. One of the key respondents in Gurgaon was an Ex-Army Captain, who noted that the goal of this committee was to raise awareness amongst the villagers in the area about the expected displacement and dispossession of land and livelihoods due to the planned acquisition, and to demand fair compensation for the land acquired for the SEZ (Interview Gurgaon, December, 2009).

It therefore appears that the main objective of the resistance movement, right from the inception of the KJS, was to demand higher compensation which was likely to disproportionately benefit already rich, large land-holding farmers. However, the local resistance to the development of these zones also included members of the poor peasantry as 
well. ${ }^{10}$ Attempts were made by KJS to accommodate these interests, as one of the posters during a KJS meeting demanded a plot of land for each of the affected families of Scheduled Castes (SCs) and Scheduled Tribes (STs) (Shrivastava, 2007). ${ }^{11}$ This, it was hoped, would gain wider support from all sections of the local population for the resistance movement. Historically, richer farmers have often mobilised the poor peasantry for large-scale rural movements, for example, public demonstration for the lower taxes, farm subsidies on fertilisers, power and irrigation and higher prices for agricultural goods, even though most of these movements served the interests of the rich (Bardhan, 1999). We now move to explore these different class interests and the resulting axes of conflict around the SEZ which produce varied geographies of resistance.

Axes of conflicts around SEZs

To understand better the class interests and resulting axes of conflict, first a proper assessment of the land acquisition process and its accompanying monetary compensation package for SEZs in India is required. The land for SEZs is acquired with the help of the respective state governments by employing the concept of 'eminent domain' i.e. land acquired for 'public purposes' under the Land Acquisition Act of $1894 .{ }^{12}$ The government compensates the landholders with the prevailing market price of the land in the area. ${ }^{13}$ People in the affected villages received US \$ 42,000 per acre for their land (Interview Village Head Garhi Harsaru, Gurgaon, December 2009). 
The rationale of the government officials in favour of this type of monetary compensation is that once the money is given to these farmers they can buy land elsewhere. One of the government officials in the EPCES, Ministry of Commerce and Industry said,

'The money awarded to the villagers is sufficient enough for them to lead a better life than before. Locals can invest in other activities namely purchasing property, setting up small business, shops and other investment opportunities in banking and stocks etc'. (Interview New Delhi, November 2009).

However, the success of investments by peasants in other livelihood opportunities depends on a number of factors. While low levels of skills, education and a lack of knowledge about business ideas are critical factors, the most important one is the amount of compensation received by the affected families. We argue that this type of monetary compensation is inadequate especially for small and marginal farmers, as the discussion below will show it does not provide a long-term solution to the loss of livelihoods associated with land dispossession. The majority of the respondents in the area were of the opinion that this type of monetary compensation awarded by the government was inadequate and were highly dissatisfied (Figure 2).

Furthermore, this type of compensation also gives no consideration to the family size of the displaced or dispossessed. A family of eight would have gotten the same amount as a family of four or fewer. Thus, bigger families would find it disproportionately more difficult to meet their livelihood needs when the only source of their future income is the fixed amount they received, and lesser chances of purchase of agricultural land elsewhere. It is hard for smaller 
farmers to buy land because the prices of land rose exponentially in and around Gurgaon. The growth of IT industry in Gurgaon has increased the demand for residential and commercial spaces which has contributed to the real-estate boom in the city. This has further put pressure on the land prices to escalate enormously and the price for an acre of land during the time of fieldwork in 2009 range from US \$ 50,000 to more than US \$ 100,000 per acre depending upon the location of the land (Interview, a property dealer, Gurgaon, December, 2009). At certain places the prices are as high as US \$ 354,000 per acre (Government of Haryana, 2011).

One of the respondents, Narayan, lost less than an acre of his land to the SEZ. He received US\$ 33,000 as compensation. He used to earn INR 2000-3000 a month from farming his land which is roughly US \$ 36.6 a month or, around US \$ 1.25 a day, the poverty line set by the World Bank. The policy makers expect him to live off the compensation money for his entire life. However, at US \$ 1.25 a day, he would manage to spend the entire compensation amount on himself in around 75 years. Now if we divide this amount among the six members of his family, each needing roughly the same amount, the money will then be spent in approximately 12 years. He said,

'But they (policy makers) should ask themselves, can they manage their family affairs with that much money?’ (Interview Gurgaon, December, 2009).

Respondents were asked to identify the main axes of conflicts regarding the SEZ. It appeared that there are two main axes - the land acquisition for the SEZ and the monetary compensation for the land (Table 1). However, it seems there are differences in the nature of 
opposition among the respondents. For example, the majority of the small and marginal land holding farmers said land acquisition was their main grievance against SEZs because of the impending dispossession. Yet, they accepted the compensation cheques offered by the government (Table 1). The expropriation of land by the state may lead to the destruction of already existing livelihoods with provisions of long-term alternative prospects such as formal employment in SEZ looking gloomy, more discussion on this later in the article. Small farmers who had accepted the compensation cheques initially thought that access to large sums of money instantly would solve some of their monetary problems (such as debt). It is true that compensation brings temporary relief to these often in-debted small farmers. However, in the absence of other immediate employment opportunities, monetary compensation alone would not be the best option as the money runs out and their dependable source of income (farming) already gone (Respondent Interview Gurgaon, December, 2009).

On the other hand, large land holding farmers were of the opinion that the compensation amount was the main issue. The majority of the thirteen respondents who refused the compensation cheques belonged to the large land holding farmers' category (Table 1). As it turned out locals received monetary compensation according to 2006 prices of the land when this project was first announced, but the cheques were distributed a year later in 2007 during which the prices went up tremendously (Interview, property dealer in Gadauli village, January, 2010).

However, the richer farmers who did accept the compensation received huge amounts of money in comparison to the smaller farmers and have been able to purchase land elsewhere primarily for real estate. While some of the richer peasantry who have resources and links at 
their disposal have lodged court cases against the government for better remuneration. For example one respondent, Rajeev who is a lawyer by profession in the District court of Gurgaon, has took the matter to the court. He said,

The government has valued every piece of land equally, without considering the location factor' (Interview Gurgaon, December, 2009).

The contradiction of locals accepting the monetary compensation and yet complaining about it is a component of how the neoliberal policies interact with socio-political structures of the countryside reflecting class interests and the perception around land. Land is critical to the class identity of both small and large farmers, but for different reasons. Land is an asset which has a monetary value, thus is a status symbol for richer farmers who have built their wealth around its possession. Poor farmers on the other hand secure their subsistence through land and see it as a source of continuous livelihood. Many of the socio-economic inequalities in rural India are built around the ownership of land which are altered due to land acquisition for SEZs. To make this matter clear, the next section discusses the differential impacts of the land acquisition for SEZs among different sections of society. We argue that the nature of the SEZ policy provides opportunities for wealth accumulation among the rural elites, while poor and marginalised sections of the population experience poverty and income decline. This has become a source of conflict among the different classes of the rural population, resulting in varied geographies of resistance. The fact that the land acquisition for SEZs widens the gap between rich and poor meant that the demands of different social groups also varies in the context of the intrusion of capitalist economy in rural areas. Rural elites see land acquisition for SEZ as an opportunity for accumulation therefore demand higher monetary compensation. 
Rural poor, however, see land acquisition as a threat to their livelihood and their demand is for the reversal of the policy or greater protection from the impacts of land acquisition.

\section{Differential impacts of the SEZ}

\section{Land ownership and employment status}

India's rural political economy is shaped by land ownership, which has given rise to various social identities (Cassan, 2013). Any change in the ownership of the land is going to affect different social identities such as class and caste based, both of which often intersect each other as a marker of social difference (Corbridge et al. 2013). The SEZs policy affects land ownership and hence the occupational status and income inequality among local populations. One of the foremost impacts of the SEZs is the concentration of land ownership among the respondents towards the landless or small and marginal category land holdings (Table 2). This suggests that land owners will be cultivating a smaller area and hence will have lower output, unless the yield per hectare increases. The withdrawal of the farm support system (also an element of neoliberalisation) leaves these small-scale farmers, particularly, in a more vulnerable position than they were before, with both central and state government's support through subsidised seeds, irrigation water and farm electricity diminishing (Shiva, et. al. 2003). They are thus caught in a neoliberal scissor, and these combined processes together contribute to the high rates of small farmer suicides in the country. ${ }^{14}$

The development of an SEZ takes a long time before it becomes functional. During the period when SEZs remain non-functional, the land acquisition pushes the poor into further disempowerment and marginalisation. It is clear that both casual labour and unemployment significantly increased among the respondents in Gurgaon soon after the land acquisition took 
place (Table 3). To expect the rural poor to achieve economic prosperity based on future employment in SEZs would be illogical.

Since, the majority of the SEZs in India are in the IT sector which requires a largely skilled work force. This labour force would be sourced from nearby urban centres, rather than those displaced by these zones in rural areas, who are mainly unskilled for the IT sector. Even though the total 'new' employment generated by SEZs established under the SEZ Act of 2005 is 995,822 people as of September 2014 (Ministry of Commerce and Industry website), majority of it is unsuited to the rural poor. However, some employment is generated outside the SEZs in the form of temporary, low paying and insecure work involving construction and security work (Levien, 2011, 2013a; Gopalkrishnan, 2007). Evidence from other functional zones in India suggests that they have also become sites of devaluation of education of workers who work in casual jobs and unprotected labour relationship, and thus institutionalisation of 'insecurity and precariousness' offer little prospects for the upward mobility of rural population (Cross, 2009: 370).

In the absence of new and quality employment generated by the SEZ suitable for the rural poor (Levien, 2011, 2013a; Gopalkrishnan, 2007), the problem of small and marginal farmers is compounded by lack of access to land. The monetary compensation amount for the small farmers was not sufficient for them to purchase land nearby because the development of the SEZ increased the prices of land in the vicinity (See page 12 above). There is also evidence of ten families who had moved further into to the rural areas, as far as $50 \mathrm{~km}$, in search of land (Interview, village head Mohammadpur, December 2009). Those who managed to buy some land are cultivating a smaller area than before. For example, a respondent, Ranvir, lost 
2 acres of land and was able to purchase only half an acre near a small town, Pataudi lying a further 26 kilometres south of the Gurgaon city (Interview Gurgaon, December 2009).

While small farmers have witnessed relative decline of land ownership, the wealthier farming class of the area has experienced little change in their land ownership (Table 2). This is due to the fact that richer landowning farmers received larger amount of compensation, which they were able to invest in other entrepreneurial activities. ${ }^{15} \mathrm{~A}$ big land owning farmer in the area Nandram had eight hectares of his land acquired for the SEZ. Subsequently, he bought more land in the nearby areas but not for farming purposes. Currently, he has around 18 hectares of land, but not in the same village. His first purchase of land cost him around US \$ 66,000 per acre. He started selling those plots of land at a rate of about US \$ 115,000 per acre (Interview Gurgaon, January 2010).

The prospects for socio-economic development of landless workers are grimmer than landowning farmers. Landless peasants are tied to the landed class through local power relations that have been key to the making of modern India. The literature on Indian agrarian studies has repeatedly pointed out that local power arrangements, such as tied rural relations in land, labour and credit and other forms of social services are central instruments of social control and capital accumulation (Hart, 1986, Bharadwaj, 1985, Brass, 1990). Thus, they have also created 'unfreedom' in the context of agrarian class relations (Harriss, 1982, Ramachandran, 1990). Landless workers in the area near the SEZ, who used to work on the farms of richer farmers on a seasonal basis have lost access to the land and related work. Thus, they could be considered as 'occupationally displaced'. They have occasionally found work in Gurgaon at various construction sites. The introduction of the SEZ and land 
acquisition have given them 'freedom' from rural labour market and upper class domination. However, another kind of 'unfreedom' is setting in i.e. urban labour market. Number of recent studies have shown that class and caste based identities continue to affect people's capacity to participate in the growing knowledge based capitalist economy in urban India (Fuller and Narasimhan, 2007; Jeffrey, et al. 2008; Harriss-White 2003).

This new form of 'unfreedom' is radically different from rural socio-political relations where personal interactions with the rural elites often keep the rural poor tied to the existing class configuration. Since the landless farmers are not the owners of any property or assets, they are left with no choice but to sell their labour power in the market centres of the new economy gaining ground in urban India. The rural poor find it hard to interact and understand the workings of these new economic spaces of India. The exploitation of these landless workers by market forces will become more evident as capitalism penetrates more deeply into the countryside. Already, the laws around SEZs prevent any form of labour unions inside the zones and working conditions and wage rates have been found to be lower than the prevailing official rates for SEZs. ${ }^{16}$

\section{Income Inequality}

The fact that the land acquisition for the SEZs generally increases landlessness and casualization of labour means that income declines amongst the local population may be imminent. Table 4 shows that the proportion of the respondents who were in the annual income bracket of less than US \$ 450 before the land acquisition has increased significantly after land acquisition. Small farmers have experienced their income-generating opportunities decline. The lack of alternative opportunities for employment has made them more 
vulnerable to income uncertainty. Since much of the income generated by these small and marginal farmers is dependent upon farming, loss of land available for cultivation meant their overall income also declined substantially.

On the other hand, the introduction of SEZs in the rural areas has increased the opportunities for income among the already rich farmers. Higher amounts of compensation enabled these big farmers to invest in other income earning activities, primarily property development. Additional work in the non-farm sector by their family members meant that income generation opportunities have increased for them in comparison to the poor peasantry.

Since the economic reforms began in India, there is evidence of widening income inequality around the country (Pal and Ghosh, 2007). This widening gap between the rich and the poor is a prominent feature of neoliberalisation in India and globally. There has been a consolidation of the wealth and assets among the rural and urban elites (Jayadev et al, 2011). The top $10 \%$ of the population possess more than half the total wealth in India (whether measured in terms of assets or net worth) (Jayadev et al, 2011). The penetration of the neoliberal economic framework and policies such as SEZs in the rural areas is creating further concentration of wealth and assets (mainly land which is the main source of income and wealth for the rural population) in the hands of the rural, and also now urban, elites. This has the potential to exacerbate the conflict between the rich and poor. Also, as the poor are further marginalised into poverty due to neoliberal schemes like SEZs, the appearance of resistance movements against these policies are also becoming common. The Indian state does everything in its power to neutralise this resistance by seeking class specific tactics designed for a particular movement and location, to which we turn now. 


\section{Breaking up the resistance movement}

Historically, Indian political economy is built on a strong state-peasant relationship (Bardhan, 1999; Frankel, 2006). The peasantry finds itself closer to the state and the corporate capitalist class is seen as an outsider to the rural setting and an element of distrust remains among the peasantry. As one of the respondents said,

'if Government would have taken the land and built schools and colleges or any industries then we would not have raised our voices. But why are they giving land to the Reliance' (Interview, Gurgaon January, 2010)?

However, since the introduction of the economic reforms of the 1990s, the Indian state has become increasingly inclined towards neoliberal policies. There is a clear ascendency of corporate capitalist class in comparison to landed rural elites. This has given rise to all sorts of claims and demands on the part of the peasantry from the government not just through 'constitutionally defined rights and laws, but also through temporary, contextual and unstable arrangements arrived at through direct political negotiations' (Chatterjee, 2011: 24). The politics of resistance movements, revolts and agitations which were previously characterised by community solidarity has now become more calculative with a utilitarian logic dominating to draw attention to specific grievances. Corbridge et. al., (2013: 304) while analysing the paradox of democratic deepening in India and neoliberal ascendency among the policy makers argued that these twin processes have given rise to competition between different 
social groups for advantage in access to state resources rather than accountability of the state to its citizens. This opens up spaces of negotiations for the government, whose primary concern now is economic growth led by private investments both foreign and domestic. Therefore, the government tries to break up compensation seekers by specific demographics and social identity: hence dividing the potential opposition to the state and its neoliberal policies (Corbridge et. al., 2005).

The idea of divide and rule has been a long tactic in the Indian colonial historiography (Stewart, 1951). The British administration hardened the caste based identities thus shaping strong divisions in the Indian society and applied this tactic to maintain control and authority over the Indian territory and its population (Dirks, 2001). In the post-colonial Independent India, the state adopted this tactic by promoting class accommodative politics for social change (Frankel, 2006) which ensured that coordinated resistance by those marginalised never gained against the state. Where necessary, resistance movements against the state policies were regularly put down to defend national interests (the case of various separatist movements in India), similar to the case of the Indian "mutiny” of 1857.

In the neoliberal era, government policies face stiff opposition from rural subjects and this hampers the Indian government's objective of bringing globalisation to the countryside. Therefore, the Indian state instead of using force, tries to breaks up these resistance movements by luring the affected with the economic gains of neoliberal economy. The state applies a variety of tactics such as appeasements of rural elites, with money and other favours, who are willing to participate in the neoliberal economy in particular. In the case of the land dispossession movement, the government can offer a variety of compensation 
packages suited to different classes that can defuse the resistance. Where this is not possible, the government tries to acquires land by using extra-economic coercion or its 'monopoly on violence' to quell any resistance against its grander neoliberal objective, as was the case in Nandigram, West Bengal.

In Gurgaon, once the resistance movement gained popularity and hampered the land acquisition for the SEZ, the state government announced that it would offer a royalty fund; payment given to the land owners over a number of years in addition to the monetary compensation already given for land. This was primarily done to gain the favour of the rural elites and sweeten the deal for easy acquisition. In the words of Mahesh, a large land owning farmer on the issue of royalty fund,

I am not against this zone. We wanted proper compensation. Once the government announced that it will pay a royalty fund for the land for the next 33 years, we stopped our movement. (Interview Gurgaon, December, 2009).

Another tactic adopted by the state government of Haryana announced additional compensation to landless farmers. One of the government officials in EPCES said,

'the government had planned to give 25 percent of the price of the total land on which these landless labourers work apart from the compensation paid to the land owning family'. (Interview New Delhi, January, 2010) 
However, there is no such clause in the old Land Acquisition Act of 1894 (which was used to acquire land for this SEZ) for compensation to be paid to the landless. ${ }^{17}$ Moreover, this $25 \%$ compensation is not at pan-Indian level, but rather confined to Haryana. There is no evidence of any such compensation having been awarded to the landless farmers in the area. This was announced as a response to try to curtail the resistance among the rural population.

Finally, private capitalists also try to reach out to rural elites, the power holders in the rural areas to break down the resistance of the local population (Shrivastava, 2007). For example, in Gurgaon one of the respondents, and ex-army man Ramakant, who belonged to a wealthy land-owning family, along with Captain S. Singh was one of the first people in the area who initiated the protest movement against the SEZ and its compensation package. However, Ramakant later withdrew from the resistance movement. One of the shopkeepers in the village told that Ramakant was offered extra money and a job as the Security Officer of the SEZ by Reliance. Captain S. Singh said,

'Personal interests of the people involved actually took away the strength of the movement. Eventually, I had to also withdraw myself' (Interview New Delhi, December, 2009). 


\section{Conclusion}

Neoliberal economic policies in India have been at the centre of nation-wide resistance movements and discontent among the poor masses of the country against the globalisation of the countryside. Yet, economic policies based on a neoliberal framework continue to be introduced and implemented. We explained this paradox by analysing some of the features of the workings of the neoliberalism in India. Much of the decision making process of neoliberalisation happens at the "top" but its applications occur primarily at the "ground" level. Neoliberal policies interact with very distinct local political and historical processes across the country. Therefore, it is at the ground level that the neoliberalism's successes and failures are most clear. We argued that neoliberal policies for economic development are gaining favour in India because they have generated enormous wealth in the country for the political and economic elites. Secondly, neoliberal economic policies generate varied geographies of resistance that are easily countered by the state. This enables the continued spread of neoliberal globalisation in the countryside.

One such policy introduced by the Indian government was SEZs, which despite widespread opposition, continue to develop all over the country. Using the specific case of the SEZ in Gurgaon, we argued that the success of the neoliberal policies gaining ground at the national level relates to the wealth accumulation opportunities for the country's economic elites. We analysed the differential impacts of the land acquisition on the lives and livelihoods of those whose land was acquired. We found that land acquisition for SEZs in India has the potential to increase poverty among the masses and widen the gap between the rich and the poor. The expropriation of land with the active role of a 'land broker' state (Levien, 2013a) allows 
private capitalists to accumulate land, which can later be converted into capital either through the extraction of rent or through production activities (agricultural, industrial or services). The case study of Gurgaon SEZ also showed that, outside of corporate capital, it is the richer peasantry who were the main beneficiaries of the land acquisition process. Policies like SEZs help redistribute the wealth and asset ownership among the political economic elites of the country thereby enhancing their class power and further enabling the continued spread of neoliberal globalisation in the countryside.

Finally, we also show that the neoliberal globalisation in India is further strengthened by the fragmented nature of resistance which confronts it. We showed that the varied nature of and less coordinated resistance movement against the SEZ in Gurgaon enabled the state and the private sector to easily counter the opposition through class specific tactics. We argue that the Indian state and the corporate elites have found an ally in the shape of the rural elites with large land holdings who are willing to let go of their land under certain socio-economic conditions where their class status is maintained under the capitalist economy. We did not suggest that this is true throughout India. Instead, we want to make a case that where class differences are not as pronounced as in Haryana, the neoliberal goal of expanded and deepened capital accumulation may meet more sustained opposition that may not be easily broken down simply by 'divide and rule' tactics and the lure of economic privileges. There are many examples of increasing resistance movement against the globalisation in some of the poor states in eastern parts of India such as Orissa, West Bengal, Chhattisgarh, Jharkhand and Bihar (see Bose; 2010; Guha, 2007; Gupta, 2006; Kunnath, 2006; Ray, 1988 on Naxalism and Maoism’s history and ideology; Nilsen, 2010 on Narmada Bachao Andolan; and Gayer and Jaffrelot, 2009 on various kinds of armed struggle in India). A case in point is the West Bengal's rural political economy which is built around the rights of small and 
marginal farmers. The SEZs policy in West Bengal faced heavy opposition and the resistance movement most notably against the ill-fated SEZ in Nandigram which saw the state government use force against the villagers. In fact, the resistance movement against that SEZ led to the fall of the Left Front government in West Bengal after 33 years of rule.

Neoliberal globalisation is likely to continue to penetrate the rural political economy of India with the Indian state using extra-economic coercion or monopoly of violence to facilitate capital accumulation. Neoliberal economic policies interact with local geographical and historical forces producing varied geographies of capital accumulation and resistance distinct from one another, even if they often share common features such as increased inequality. We can further develop our understanding of the continuously changing politico-economic landscape of India through further assessment of such different cases which will enhance our knowledge of the workings of neoliberal form of capitalism in different parts of the world.

\section{Acknowledgment}

The authors would like to thank the Foundation for Urban and Regional Studies for travel grant to support the fieldwork for this study and Trinity College Dublin for funding the research. We also gratefully acknowledge the comments of the referees and editor which have substantially improved the paper. Also, special thanks to Chris Rogerson for his feedback that improved this paper. 


\section{References}

Agamben G (2005) State of Exception, tr. Kevin Attell, The University of Chicago Press: Chicago.

Ahmad W (2014) The political economy and geopolitical context of India's economic crisis, 1990-91, Singapore Journal of Tropical Geography, 35(2), 179-96.

Anwar M A (2014) New modes of industrial manufacturing: India's experience with special economic zones. Bulletin of Geography. Socio-economic Series. 24, 7-25. DOI: http://dx.doi.org/10.12775/BGSS.2014.011.

Banarjee-Guha S (2008) Space relations of capital and new economic enclaves: SEZs in India. Economic and Political Weekly, 43(47), 51-59.

Bardhan P (1999) The political economy of development in India. Oxford University Press: New Delhi.

Baviskar, A. (1998) In the Belly of the River: Tribal Conflicts over Development in the Narmada Valley. Oxford University Press: Oxford.

BBC News (2009) India boom threatened by slowdown, BBC, March 27, Article dated March 27, 2009 can be found online at http://news.bbc.co.uk/2/hi/business/7968138.stm, (Accessed on July 1, 2015).

Bharadwaj K (1985) A view on commericalisation in Indian agriculture and the development of capitalism, Journal of Peasant Studies, 12 (4), 7-25.

Bose, P (2010) Maoism: a critique from the left, LeftWord Books: Delhi.

Brass T (1990) Class struggle and the deproletarianisation of agricultural labour in Haryana (India), Journal of Peasant Studies, 18 (1), 50-77. 
Brass T (1999) Towards a comparative political economy of unfree labour: case studies and debates, Library of Peasant Studies No. 16, Frank Cass and Co. Ltd: London.

Business Today (2009). The Top Five cities, June 28, Available online at http://businesstoday.intoday.in/bt/story/the-top-five-cities.html/1/4265.html, (Accessed on March 1, 2011).

Cassan G (2013) Identity Based Policies and Identity Manipulation: Evidence from Colonial Punjab, American Economic Journal: Economic Policy, Draft available online at https://www.aeaweb.org/forthcoming/output/accepted_POL.php. (Accessed on January 07, 214).

Chatterjee P (2011) Democracy and economic transformation in India. In Ruparelia, et. al (ed) Understanding India's new political economy: a great transformation? 17-34, Routledge, London and New York.

Citizens Research Collective (2007) SEZs and land acquisition: factsheet for an unconstitutional economic policy, undated manuscript. Available online at http://www.sacw.net/Nation/sezland_eng.pdf (Accessed on January07, 2014).

Corbridge S and Harriss J (2000) Reinventing India: liberalisation, hindu nationalism and popular democracy, Polity Press and Blackwell: Cambridge.

Corbridge S, Harriss J and Jeffrey C (2013) India today: Economy, politics and society, Polity press: Cambridge and Malden.

Corbridge S, William G, Srivastava M, Veron R (2005) Seeing the state: governance and governmentality in India, Cambridge University Press: Cambridge.

Cross J (2009) From dreams to discontent: educated young men and the politics of work at a Special Economic Zone in Andhra Pradesh. Contributions to Indian Sociology, 43(3), 35179. 
Dirks N (2001) Castes of mind: colonialism and the making of modern India, Princeton University Press: Princeton and NJ.

Government of India (2009) Annual Report 2008-09, Department of Commerce.

Fernandes W (2008) Sixty years of development induced displacement, in Mathur HM (ed) India social development report 2008: development and displacement, Oxford University Press, New Delhi.

Frankel F (2006) India’s political economy 1947-2004. Oxford University Press: Oxford; New Delhi.

Fuller C J and Narasimhan H (2007) Information technology professionals and the new rich middle class in Chennai, Modern Asian Studies, 41(1), 121-50.

Gayer L and Jaffrelot C (2009) Armed militias of South Asia: fundamentalist, maoists and separatists, Hurst and Company: London.

Goldman M (2011) Speculative urbanism and the making of the next world city, International Journal of Urban and Regional Research, 35 (3), 555-81.

Gopalkrishnan S (2007) In the name of growth: the politics and economics of special economic zones in India, Study prepared for Council for Social Development New Delhi. Available online at http://sanhati.com/wpcontent/uploads/2007/05/in_the_name_of_growth_final_with_changes.pdf. (Accessed on January 07, 2014).

Government of Haryana (2011) Revised rates for agricultural land and plots for the year 2010-11, District Gurgaon portal, Available online at http://www.scribd.com/doc/36272576/Circle-rates-2009-2010-in-Gurgaon-For-Flats-Plotsand-Agricultural-Land-Gurgaon-Property-Qubrex-com\#scribd, (Last Retrieved on May 28, 2010). 
Guha R (2007) Adivasis, naxalites and Indian democracy, Economic and Political Weekly, 42 (32), 3305-12.

Gupta T D (2006) Maoism in India: ideology, programme and armed struggle, Economic and Political Weekly, 61 (2), 3172-6.

Harriss J (1982) Capitalism and peasant farming: agrarian structures and ideology in northern Tamil Nadu, Oxford University Press: New Delhi.

Harriss-White B (2003) India working: essays on economy and society Cambridge University Press: Cambridge.

Hart G (1986) Interlocking transactions: obstacles, precursors or instruments of agrarian capitalism? Journal of Development Economics, 23(1), 177-203.

Harvey D (2005) A brief history of neoliberalism, Oxford University Press: Oxford.

Jayadev A, Motiram S, Vakulabharanam V (2011) Patterns of wealth disparities in India: 1991-2002 in Ruparelia et. al. (eds) Understanding India's new political economy: a great transformation? 81-100, Routledge, London and New York.

Jeffrey C, Jeffery P and Jeffery R (2008) Degrees without freedom: Education, masculinities and unemployment in North India, Stanford University Press: Stanford.

Jenkins R (2011) The politics of India’s special economic zones in Ruparelia, et. al (eds) Understanding India's new political economy: a great transformation?, 49-65, Routledge, London and New York.

Jodhka SS (2012) Agrarian changes in the times of (neo-liberal) 'crises': revisiting attached labour in Haryana. Economic and Political Weekly Supplement, 47(26 \& 27), 5-13.

Kunnath G (2006) Becoming a Naxalite in rural Bihar: class struggle and its contradictions, Journal of Peasant Studies, 33(1), 89-123. 
Levien M (2011) Special economic zones and accumulation by dispossession in India. Journal of Agrarian Change, 11(4), 454-483.

Levien M (2013a) Regimes of dispossession: from steel towns to special economic zones. Development and Change, 44(2), 381-407.

Levien M (2013b) The politics of dispossession: theorising land wars in India. Politics and Society, 41(3), 351-394.

Mathur H M (2008) (ed) India Social Development Report 2008: Development and Displacement, Oxford University Press: New Delhi.

National Commission for Scheduled Tribes (2007) Second Report for the year 2006-07, NCST, New Delhi, Available online at http://ncst.nic.in/writereaddata/linkimages/NCST\%20II\%20Report\%20in\%20English341193 272.pdf, (Accessed on May 02, 2015).

Nilsen A G (2010) Dispossession and Resistance in India: the river and the rage, Routledge: London and New York.

Pal P and Ghosh J (2007) Inequality in India: a survey of recent trends, United Nations Department of Economics and Social Affairs, Working Paper No. 45. Available online at http://www.un.org/esa/desa/papers/2007/wp45_2007.pdf. (Accessed on January 07, 2014).

People’s Tribunal on Nandigram (2007) Executive summary of the report, May 2007, Available online at http://sanhati.com/wp-content/uploads/2007/08/people_stribunal.pdf, (Accessed on June 15, 2015).

Ramachandran V K (1990) Wage labour and unfreedom in agriculture, Oxford University Press: New York.

Ray R (1988) The Naxalites and their ideology, Oxford University Press: New Delhi. 
Shiva V, Jafri A H, Jalees K (2003) The mirage of market access: how globalisation is destroying farmers lives and livelihoods. Navdanya/Research Foundation for Science Technology and Ecology, New Delhi.

Shrivastava A (2007) The growing revolt against disposability, Radical Notes 03 May. Available online at http://radicalnotes.com/2007/05/03/the-growing-revoltagainst-disposability/(Accessed on January 07, 2014).

Stewart N (1951) Divide and rule British policy in Indian history, Science and Society, 15 (1), 49-57.

Teltumbde A (2012) SC/STs and the State in the Indian Constitution, Counter Currents, Available online at, http://www.countercurrents.org/teltumbde060212.pdf, (Accessed on May 02, 2015).

The Telegraph (2009) 03 August. Available online at http://www.telegraphindia.com/1090803/jsp/business/story_1131403, Last Accessed on March 18, 2010.

The Times of India June (2006) 20 June. Available online at http://articles.economictimes.indiatimes.com/2006-06-20/news/27454860_1_relianceharyana-reliance-signs-hsiidc, (Accessed on July 02, 2015). 


\section{Tables}

Table 1: Nature of opposition among the respondents in Gurgaon

\begin{tabular}{|c|c|c|c|c|c|c|}
\hline & & \multicolumn{2}{|c|}{$\begin{array}{l}\text { Number of respondents who } \\
\text { accepted compensation cheques }\end{array}$} & \multicolumn{3}{|c|}{$\begin{array}{l}\text { Number of respondents who } \\
\text { refused compensation } \\
\text { cheques }\end{array}$} \\
\hline & & $\begin{array}{l}\text { Small/marginal } \\
\text { farmers }\end{array}$ & $\begin{array}{l}\text { Medium/Larg } \\
\text { e farmers }\end{array}$ & & $\begin{array}{l}\text { Small/marginal } \\
\text { farmers }\end{array}$ & $\begin{array}{l}\text { Medium/Larg } \\
\text { e farmers }\end{array}$ \\
\hline $\begin{array}{l}\text { Nature of } \\
\text { opposition }\end{array}$ & & & & & & \\
\hline $\begin{array}{l}\text { Land } \\
\text { acquisition }\end{array}$ & 25 & 14 & 11 & 1 & - & 1 \\
\hline $\begin{array}{l}\text { Monetary } \\
\text { compensatio } \\
n\end{array}$ & 13 & 6 & 7 & 9 & 2 & 7 \\
\hline $\begin{array}{l}\text { Industries } \\
\text { by private } \\
\text { developers }\end{array}$ & 4 & 1 & 3 & 3 & - & 3 \\
\hline $\begin{array}{l}\text { Total } \\
\text { respondent } \\
s(60)^{a} \\
\end{array}$ & 42 & & & 13 & & \\
\hline
\end{tabular}

Note: ${ }^{a}$ Five respondents were landless so they did not receive any compensation.

Source: Data generated during the fieldwork in Gurgaon through the interviews with the villagers. 
Table 2: Land holding pattern before and after the land-acquisition in Gurgaon

\begin{tabular}{ccc}
\hline $\begin{array}{c}\text { Size Category (in } \\
\text { hectares) }\end{array}$ & $\begin{array}{c}\text { Before Acquisition (No. of } \\
\text { respondents) }\end{array}$ & After Acquisition (No. of \\
\hline Landless & 5 & 13 \\
\hline Marginal (> one & 7 & 8 \\
hectare) & & \\
\hline Small (1 to 2 hectares) & 6 & \\
\hline Semi-medium (2 to 4 & 10 & \\
\hline hectares) & & 12 \\
\hline medium (4.0 to 10.0 \\
hectares)
\end{tabular}

Source: Data generated during the fieldwork in Gurgaon through the interviews with the villagers 
Table 3: Employment status among the respondents in Gurgaon

\begin{tabular}{lcc}
\hline Mode of employment & \multicolumn{2}{c}{ Number of respondents } \\
\hline & Before land acquisition & After land acquisition \\
\hline Casual labour & 14 & 19 \\
\hline Salaried & 9 & 11 \\
\hline Self employed & 33 & 22 \\
\hline Unemployed & 4 & 8 \\
\hline Total & 60 & 60
\end{tabular}

Source: Data generated during fieldwork in Gurgaon through interviews.

Table 4: Income level of the respondents before and after the land acquisition in Gurgaon

\begin{tabular}{ccc}
\hline Annual Income category & Before land acquisition (number of & After land \\
$(\mathrm{US} \$)$ & respondents $^{\mathrm{a}}$ ) & acquisition \\
\hline
\end{tabular}

Below Rs. 2000 (less than US

\$450)

11

18

Rs. 2000-4000 (US 450- 897)

18

13

Rs. 4000 or above (more

than US \$ 897)

27

25

Note: ${ }^{a}$ Four respondents refuse to reveal their income.

Source: Data generated during the fieldwork in Gurgaon through the interviews with the villagers 


\section{Figures:}

Figure 1: Location map of Gurgaon district (shaded area)

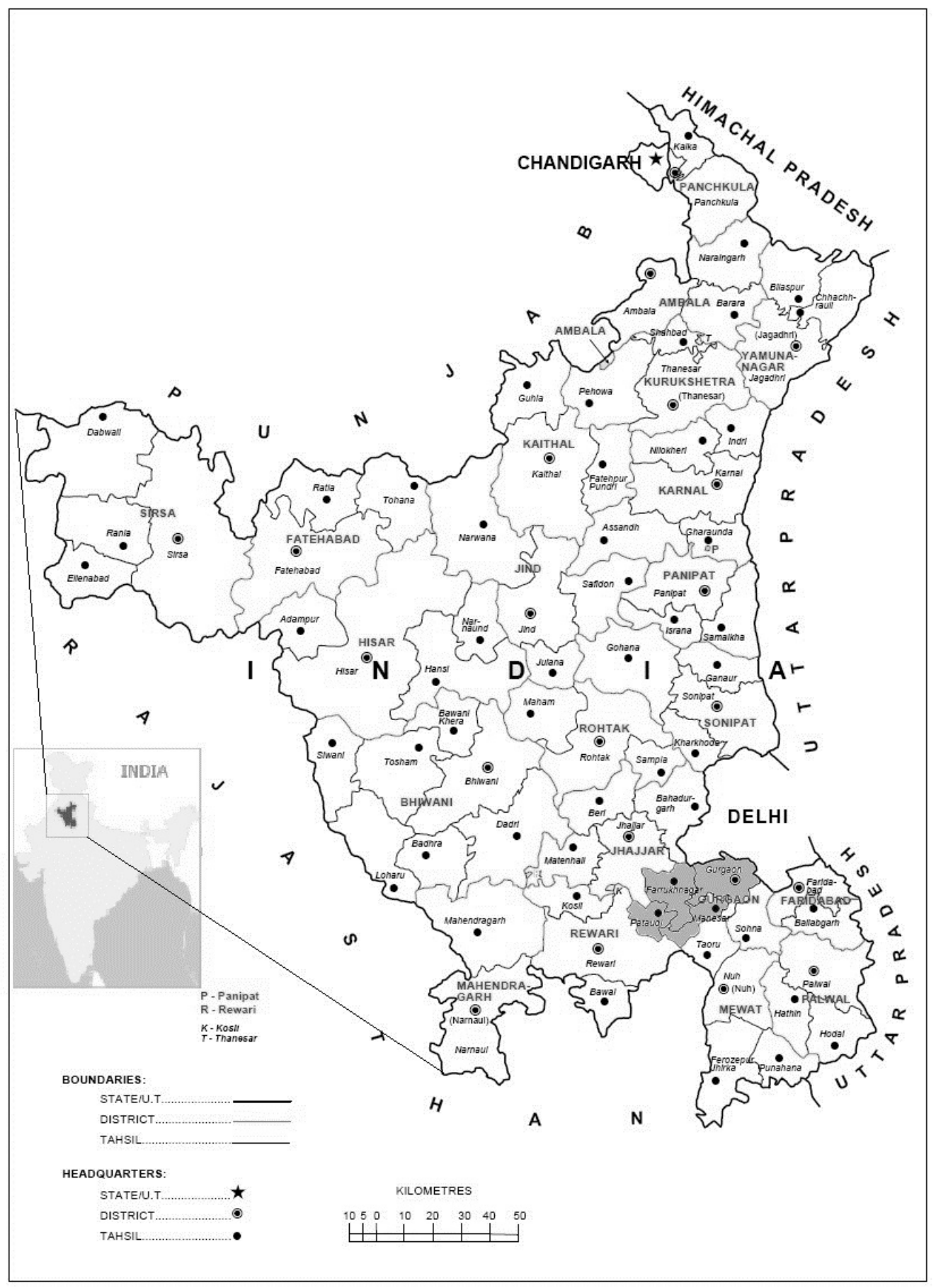


Figure 2: Satisfaction level among the villagers in Gurgaon over the compensation for land (figures in parentheses represent number of respondents)

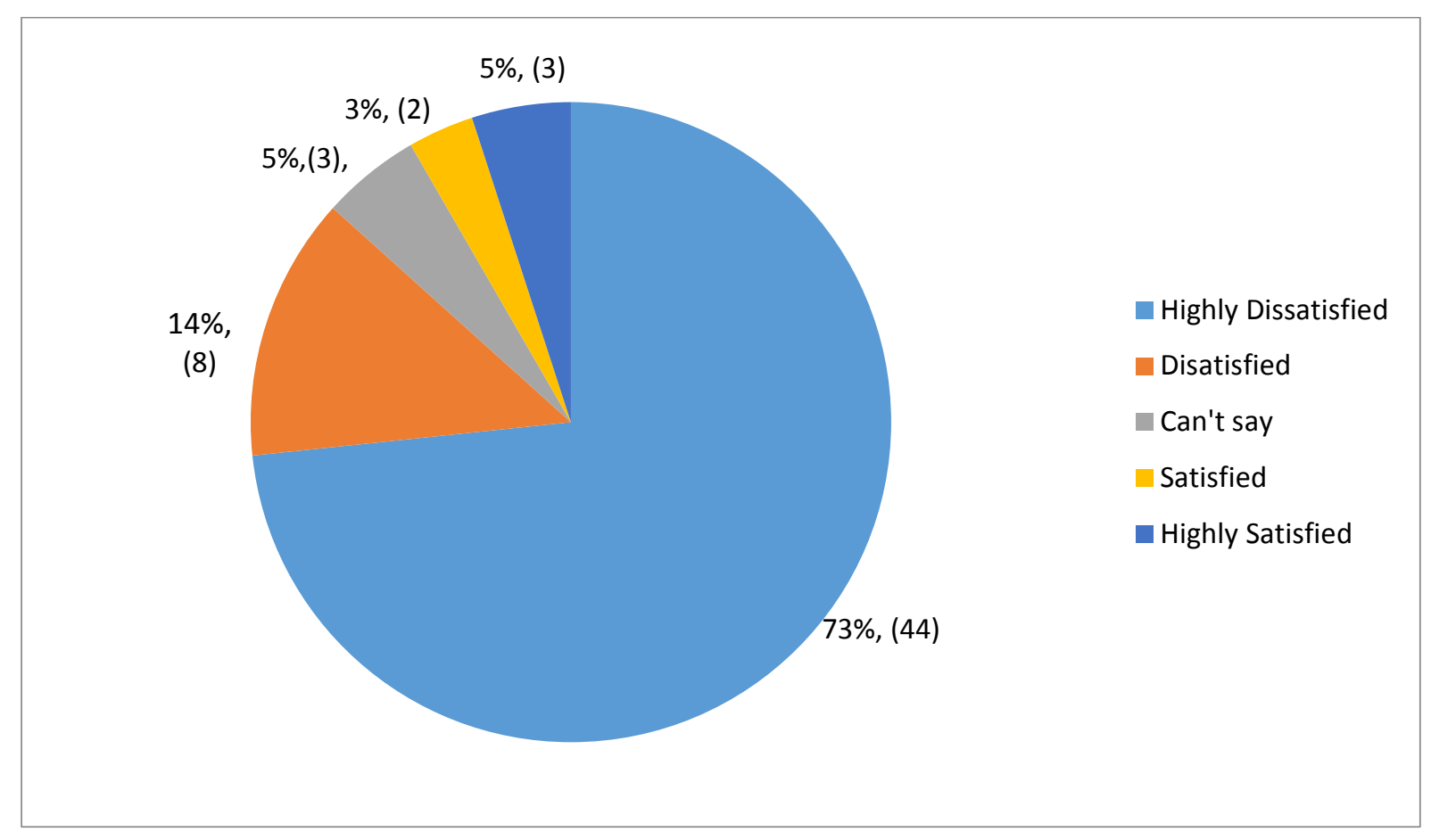

\section{Endnotes}

${ }^{1}$ Available online at http://www.youtube.com/watch?v=qzTLBkesqxU, (Accessed on July 20, 2015). 2 The sheer scale and extent of the resistance movements against SEZs in India prompted some of the observers claiming that farmers are becoming an obstacle to the economic growth in India. Several newspapers and magazines headlines were like this; 'India's biggest industrial barrier? Farmers', Globe and Mail, July 10, 2008 and 'The great SEZ rush skids on slowdown, Land Issues', Business Standard, June 28, 2009.

${ }^{3}$ SEZs were then known as Export Processing Zones (EPZs) in India. After the introduction of the EXIM Policy 2005-06, which suggested these zones to be called as SEZs modelled after Chinese zones, all the previous EPZs were renamed to SEZs. For a historical perspective on growth and development of SEZs in India refer to Anwar (2014).

${ }^{4}$ The policy environment of the Indian economy started to change slowly towards neoliberalism before the 1980s but the more thorough introduction of reforms took place in 1991 due to the crisis (See, Corbridge and Harris, 2000; Frankel, 2006; Ahmad, 2014).

${ }^{5}$ The seven Zonal DC's are in Kandla, Surat, Noida, Chennai, Cochin, Falta and Vishakhapatnam.

${ }^{6}$ SIDCs would acquire land for industrial purposes under the aegis of public sector. Refer to http://www.cosidici.com/states1.htm for details of state level industrial corporations. (Accessed on July 05, 2015).

7 India's new knowledge economy has led to the establishment of Business processes outsourcing (BPO) centres around these cities since 1991. Gurgaon's recent growth in the last decade has led to some commentators calling it "the city of India's globalisation story" (BBC News March 27, 2009). For land speculation, dispossession and the growth of IT industry in Indian cities which has given rise to 'speculative urbanism' see Goldman (2011).

${ }^{8}$ According to Business Today, a fortnightly magazine in India, Gurgaon is described as the 'callcentre capital' of India (Business Today, 2009). 
${ }^{9}$ The distinction between formally approved and notified SEZs is criticall to the understanding of the land acquisition for these zones. A developer submits a proposal for SEZ to any of the states in India. Once the proposal is received by the respective states, they forward the proposal to the Board of Approval (BOA) which constitutes 18 members from different government offices and ministries. BOA then either approves it formally or gives in-principle approval. Formal approval is given when all the terms and conditions according to the SEZ Act are met in the proposal. In-principle approval means the proposal has to be reviewed again by the developer on terms and conditions set up in the SEZ Act and the proposal can be again submitted to BOA. Once a proposal has received a formal approval, the developer then has to furnish the details of complete land acquisition over the required area for the SEZ or lease-hold rights over the identified area. This has to be done within the next three-year period. Once this is completed the SEZ is notified (SEZ Act of 2005, Government of India).

${ }^{10}$ Poor farmers are often mobilized by richer farmers in large-scale rural movements which ultimately serve the interests of the rich. See Bardhan (1999) on this subject matter.

${ }^{11} \mathrm{SCs} / \mathrm{ST}$ are identified as the economically and socially backward communities of people in India. Article 341 and 342 in the Constitution of India have provisions relating to the identification and safeguarding of SCs and STs, respectively, by the President of India or the Governor of a respective state. However the criterion for defining them is not spelt out in the Constitution but takes into account definitions used in various committees and reports (Teltumbde, 2012; National Commission for Scheduled Tribes, 2007).

${ }^{12}$ This LAA of 1894 has been replaced by a new act called as 'The right to fair compensation and transparency in land acquisition, rehabilitation and resettlement act, 2013'. The definition of the public purpose remain the same as the old Act and is often stretched to include the private sector activities as is the case with most of the SEZs in India. The land acquisition for new SEZs will be carried out using the new Act.

${ }^{13}$ This is however, a very controversial issue as the market prices can vary greatly depending upon the location of the land while the official rates on the government's register are kept at low to save Stamp Duty on land sales. Under the new Act of 2013, the Collector determines the market value of land either through the Indian Stamp Act 1899 if any, average sale price of similar type of land in the nearby village or consented amount of compensation for private companies, whichever is higher. Even this does not eradicate the old problems of government deciding the official price of existing land in the vicinity through sale deeds which are kept relatively low. Therefore, the government end up paying the landholders with the lower official rates than the real market rates.

${ }^{14}$ Rough estimate suggest that 41 farmers commit suicide in India every day (Aljazeera, 2015). Available online at http://www.aljazeera.com/indepth/features/2015/05/india-shocking-farmersuicide-epidemic-150513121717412.html, (Accessed on July 20, 2015).

${ }^{15}$ A visit to Gurgaon town revealed large number of property dealers and real estate investors all over the town. Field Notes Gurgaon, December 2009- January 2010.

${ }^{16}$ This wage differential was found in author's fieldwork in a separate case study on Falta SEZ in West Bengal where labour contractors have emerged as an intermediary for hiring of the labour inside the zone. During the interview with one of the managers of a factory inside the Falta SEZ, he told that they pay the wages to the contractor who takes his cut before finally paying the wages to the workers (Field Notes Falta, August, 2009).

${ }^{17}$ Even under the new act, the nature of full compensation and resettlement and rehabilitation award for the landless is not clear. For example, the first schedule of the new Act outlines the components of compensation for land owners and to tenants (that include landless) in a 'proportion' to be decided by the appropriate Government. The value of 'proportion is not given anywhere in the Act. 